\title{
Genetic Variability and Reproduction Structure of Corbicula japonica in Major Fishing Brackish Lakes in Japan
}

\author{
Tsudzumi Mito' ${ }^{1}$ Tomomi Tanaka², Futoshi Aranishi, ${ }^{1,2,3}$ \\ ${ }^{1}$ United Graduate School of Agricultural Sciences, Tottori University, Tottori, Japan \\ ${ }^{2}$ Center for the Promotion of Project Research, Shimane University, Matsue, Japan \\ ${ }^{3}$ Coastal Lagoon Research Center, Shimane University, Matsue, Japan \\ Email: aranishi@soc.shimane-u.ac.jp
}

Received 5 May 2014; revised 7 June 2014; accepted 23 June 2014

Copyright (C) 2014 by authors and Scientific Research Publishing Inc. This work is licensed under the Creative Commons Attribution International License (CC BY). http://creativecommons.org/licenses/by/4.0/

\section{(c) (i) Open Access}

\begin{abstract}
Corbicula japonica is the best-known bivalve inhabiting widely in brackish estuaries and lakes in Japan. Although this species has been most commercially important species of inland fisheries in Japan, the gradual decline in its production over 40 years caused not only economic problems in fishery industry but also ecological disturbances in biodiversity conservation. The aim of this study was to evaluate the reproduction structure of $C$. japonica populations in major fishing brackish lakes based on the genetic diversity inferred by mitochondrial DNA sequence analysis of the cytochrome oxidase $c$ subunit I gene. Of a total of $188 \mathrm{C}$. japonica individuals collected in Lakes Shinji, Jusan, Ogawara and Abashiri, 25 haplotypes were obtained, and only the haplotype HT01 was apparent with relatively high abundance in all lakes. Minimum spanning network analysis of haplotypes showed different population structures between Lake Shinji and Lakes Jusan, Ogawara and Abashiri. In addition, pairwise population genetic distance $F_{S T}$ and $\Phi_{S T}$ values were significantly higher in Lake Shinji than Lakes Jusan, Ogawara and Abashiri. The mismatch distribution analysis showed unimodal profile for Lakes Jusan and Ogawara and bimodal profile for Lakes Shinji and Abashiri. Those results indicate a recent population expansion in all lakes, and Lakes Shinji and Abashiri and Lakes Jusan and Ogawara maintained continuous reproduction structure and suffered to rapid population growth, respectively.
\end{abstract}

\section{Keywords}

Corbicula japonica, Brackish Lakes, Genetic Diversity, Reproduction Structure, Cytochrome Oxidase $c$ Subunit I Gene 


\section{Introduction}

Species belonging to the genus Corbicula attain an almost worldwide distribution and inhabit in estuaries, lakes, and rivers [1]-[3]. In Japan, 3 endemic Corbicula species are reproductively and developmentally heterogeneous [4]-[7]. Although C. leana and C. sandai appear fresh waters only in Japan, C. japonica inhabits blackish waters throughout eastern Asia from Kyushu Island in Japan to Sakhalin Island in Russia between approximately $27^{\circ} \mathrm{N}$ and $55^{\circ} \mathrm{N}[8]$.

C. japonica has been one of the most important species for inland fisheries in Japan [9], and occupied 99\% of the total catch of Corbicula [8]. The catch of Corbicula from 2002 to 2011 reached average 12,000 tons, which corresponded to approximately $30 \%$ of the total catch of inland fisheries [10]. As fisheries of C. japonica have so far prospered in a number of lakes and marshes, Lake Shinji in Shimane Prefecture, Lakes Jusan and Ogawara in Aomori Prefecture, Lake Abashiri in Hokkaido Prefecture, and Kiso Three Rivers in Mie, Gifu and Aichi Prefectures are recent major fishing areas [11]. However, the catch of C. japonica decreased since 1970s due to overfishing, habitat destruction and coastal pollution caused by reclamation work and estuary barrage [12]. For the purpose of an effort to promote stock restoration and increase fisheries production, seedlings and/or adults of C. japonica suffered to frequent transplantation among fishing areas. In addition, a bulk of anonymous Corbicula individuals was successively imported from eastern Asia [12]. It has been therefore concerned with the genetic disturbance of $C$. japonica in Japan, but its genetic diversity and reproduction structure are still not well understood.

Mitochondrial DNA (mtDNA) has been extensively used for both population genetic and systematic genetic studies on various taxonomic levels [13]. The mtDNA cytochrome $c$ oxidase subunit I (COI) gene has often been adopted as a tool for determining the genetic diversity of fisheries valuable bivalves in Japan [14]-[16]. The aim of this study was to evaluate the genetic variability and reproduction structure of $C$. japonica populations among 4 major fishing brackish lakes in Japan using the mtDNA COI gene. The genetic information contributes to stock management of $C$. japonica resources for long-term sustainable fisheries and aquaculture.

\section{Materials and Methods}

\subsection{Sample Collection}

A total of 188 individuals were collected from Lakes Shinji $(\mathrm{N}=45)$, Jusan $(\mathrm{N}=48)$, Ogawara $(\mathrm{N}=48)$, and Abashiri ( $\mathrm{N}=47)$ in September 2009 and August 2010 (Table 1, Figure 1). All specimens were boiled, and

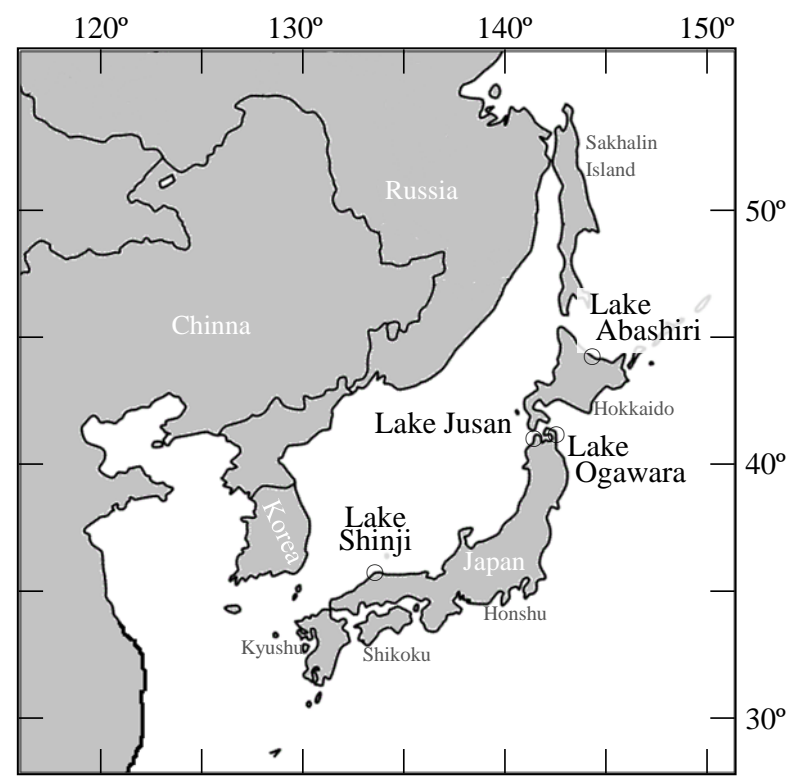

Figure 1. Map of East Asia at which open circles represent the collection sites of Corbicula japonica in Lakes Shinji, Jusan, Ogawara and Abashiri in Japan. 
Table 1. Shell length and height of Corbicula japonica collected in Lakes Shinji, Jusan, Ogawara and Abashiri.

\begin{tabular}{cccc}
\hline Lake & $n$ & SL mean $(\mathrm{mm}) \pm$ S.D. & SH mean $(\mathrm{mm}) \pm$ S.D. \\
\hline Shinji & 45 & $18.16 \pm 2.17$ & $15.87 \pm 1.76$ \\
Jusan & 48 & $26.73 \pm 2.51$ & $23.90 \pm 2.24$ \\
Ogawara & 48 & $22.34 \pm 1.43$ & $20.42 \pm 1.31$ \\
Abashiri & 47 & $24.28 \pm 1.41$ & $22.46 \pm 1.27$ \\
Total & 188 & $22.94 \pm 3.66$ & $20.73 \pm 3.44$ \\
\hline
\end{tabular}

SL, SH and S.D. represent shell length, shell height and standard deviation, respectively.

adductor muscle or foot tissue were excised from soft tissue and immediately stored at $-20^{\circ} \mathrm{C}$ until DNA extraction.

\subsection{DNA Extraction}

High-quality total genomic DNA was prepared from small scraps of frozen adductor muscle or foot tissue according to the modified urea-SDS-proteinase K method [17]-[19]. Samples were incubated in the extraction buffer (10 mM Tris-HCl, pH 7.5, $20 \mathrm{mM}$ EDTA, pH 8.0, 1\% SDS, and $4 \mathrm{M}$ urea) containing $25 \mu$ g proteinase K at $55^{\circ} \mathrm{C}$, and $5 \mathrm{M} \mathrm{NaCl}$ was then added and mixed. DNA was isolated with phenol-chloroform-isoamyl alcohol and subsequently with chloroform-isoamyl alcohol followed by precipitation with ethanol. DNA pellets were washed with ethanol, dried, and resuspended in 10T0.1E (10 mM Tris-HCl, pH 7.5, $0.1 \mathrm{mM}$ EDTA, pH 8.0).

\subsection{PCR Amplification}

PCR amplification of the mtDNA COI gene was performed in GoTaq Green PCR Master Mix (Promega) containing $2 \mathrm{mM} \mathrm{MgCl}_{2}, 0.5 \mu \mathrm{M}$ of each primer, and template DNA in a Techgene thermal cycler (Techne). PCR primers were LCO1490 5'-GGTCA ACAAA TCATA AAGAT ATTGG-3' and HCO2198 5'-TAAAC TTCAG GGTGA CCAAA AAATC A-3' [20]. PCR protocol consisted of an initial denaturation at $94^{\circ} \mathrm{C}$ for 2 min, followed by 35 cycles of $1 \mathrm{~min}$ at $94^{\circ} \mathrm{C}, 30 \mathrm{sec}$ at $50^{\circ} \mathrm{C}$, and $1 \mathrm{~min}$ at $72^{\circ} \mathrm{C}$, and a final extension at $72^{\circ} \mathrm{C}$ for $5 \mathrm{~min}$. PCR products were analyzed using a DNA-1000 Reagent Kit (Shimadzu) containing a SYBR Gold Nucleic Acid Gel Stain (Invitrogen) in a MCE-202 MultiNA microchip electrophoresis system (Shimadzu).

\subsection{Sequence Analysis}

Nucleotide sequencing of double strands of PCR product was accomplished using a BigDye Terminator ver. 3.1 Cycle Sequencing Kit (Applied Biosystems) in an automated 3730xl DNA Analyzer (Applied Biosystems). The determined sequences were edited and aligned with CLUSTAL W [21] using MEGA ver. 5.5 [22], followed by submission to GenBank under AB971384-AB971408. Haplotype network based on statistical parsimony was resolved using TCS ver. 1.21 [23]. Haplotype diversity $h$ and nucleotide diversity $\pi$ were estimated using Arlequin ver. 3.5 [24]. Pairwise $F_{\mathrm{ST}}$ and $\Phi_{\mathrm{ST}}$ values among sampling localities were calculated using Arlequin ver. 3.5 [24], following which their significance was evaluated by performing a randomization test with 10,000 replications and Bonferroni corrections [25]. Neighbor-joining (NJ) tree with bootstrap analysis was constructed on the basis of the Kimura's 2-parameter model [26] with 10,000 replications using NEIGHBOR in PHYLIP ver. 3.68 [27]. A distance matrix for all pairwise haplotype comparisons was constructed, and the maximum number of mutational differences justified by the parsimony limit of 0.95 was estimated. Mismatch distribution analysis of nucleotide sequences was performed for goodness-of-fit to simulated values of sudden population expansion by parametric bootstrapping with 10,000 replicates using Arlequin ver. 3.5 [24]. Tajima's $D$ value [28] and Fu's $F_{\mathrm{S}}$ value [29] for neutrality test were estimated from sequence variations using Arlequin ver. 3.5 [24].

\section{Results}

The average shell length and shell height of $C$. japonica individuals collected in Lakes Jusan, Ogawara and Abashiri ranged from $22.34 \pm 1.43 \mathrm{~mm}$ to $26.73 \pm 2.51 \mathrm{~mm}$ and from $20.42 \pm 1.31 \mathrm{~mm}$ to $23.90 \pm 2.24 \mathrm{~mm}$, re- 
spectively. In contrast, the respective values of those collected in Lake Shinji were determined to be $18.16 \pm$ $2.17 \mathrm{~mm}$ and $15.87 \pm 1.76 \mathrm{~mm}$, and relatively small shell size compared with the other lakes (Table 1). Fisheries cooperatives have defined minimum shell size of the catch for stock management in individual lake, and 10, 12, 15 and $14 \mathrm{~mm}$ are in Lakes Shinji, Jusan, Ogawara and Abashiri, respectively.

After editing nucleotide sequences of PCR product encoding the mtDNA COI gene, a portion of 556 bp were aligned from 188 individuals collected in 4 lakes, and 24 variable sites and no insertion or deletion were obtained (Table 2). Of 25 detected haplotypes identified to be C. japonica (Figure 2), only the haplotype HT01 was shared among all lakes with a high frequency accounting for $78.8 \%$ of 188 individuals, and remaining 24 haplotypes from $\mathrm{H} 02$ to $\mathrm{H} 25$ were unique to individual lake. The haplotype diversity $h$ values ranged from $0.2026 \pm 0.0778$ in Lake Abashiri to $0.6040 \pm 0.0566$ in Lake Shinji (Table 3). Although the frequency of the haplotype $\mathrm{H} 01$ was good correlation with the haplotype diversity, the numbers of haplotypes were poor correlation with the $h$ values. The nucleotide diversity $\pi$ values of Lakes Jusan, Ogawara and Abashiri ranged from $0.0591 \% \pm 0.0671 \%$ to $0.0601 \% \pm 0.0678 \%$, showing relatively low level diversity compared with that value of Lake Shinji to be $0.2207 \% \pm 0.1586 \%$ (Table 3).

Haplotype network obtained out of 25 haplotypes revealed star-like shape with a partly bush-like clade (Figure 3). Haplotype networks consisted of almost unique haplotypes with 1-2 substitution difference radiating from the haplotype H01, and 3 haplotypes further radiated from the haplotype H02 with 1 substitution difference only in Lake Shinji. They supposedly had a recent history of continuous reproduction, and Lake Shinji was more stable in the reproduction structure than the other lakes. These results were consistent with a markedly high level of the $\pi$ value in Lake Shinji compared with the other lakes (Table 3).

The pairwise $F_{\mathrm{ST}}$ and $\Phi_{\mathrm{ST}}$ values among 4 lakes ranged from -0.0074 to 0.2011 and from 0.0027 to 0.2715 , respectively, and both values between Lake Shinji and the other lakes were evaluated to be significant (Table 4). In addition, the NJ trees based on the pairwise $F_{\mathrm{ST}}$ and $\Phi_{\mathrm{ST}}$ values separated Lake Shinji from the other lakes (Figure 4).

In Lakes Jusan and Ogawara, the mismatch distribution appeared to be unimodal clearly, which closely matched the simulated values, whereas that in Lakes Shinji and Abashiri appeared to be bimodal (Figure 5). The

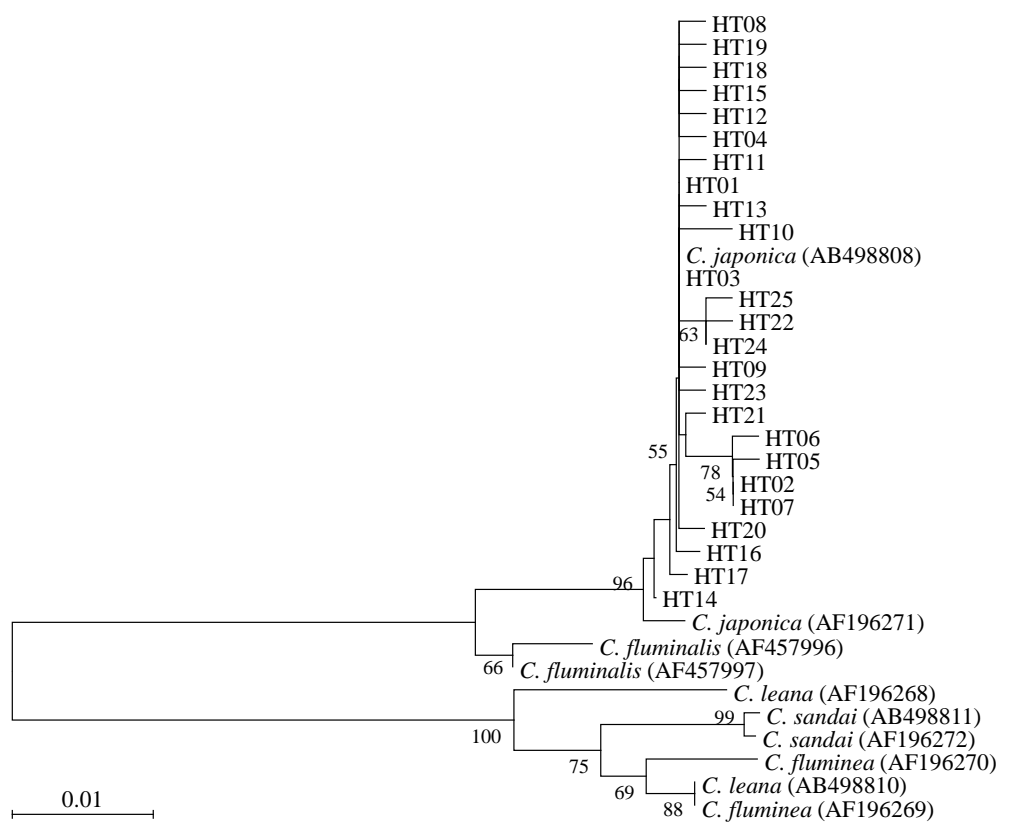

Figure 2. Neighbor-joining tree for H01-H25 haplotypes of Corbicula japonica collected in Lakes Shinji, Jusan, Ogawara and Abashiri. Sequences of $C$. japonica (AB988808, AF196271), C. leana (AB498810, AF196268), C. sandai (AB498811, AF196272), C. fluminea (AF196269, AF196270) and C. fluminalis (AF457996, AF457997) were used as reference sequences. Bootstrap values higher than 50 are shown at nodes. 
All lakes
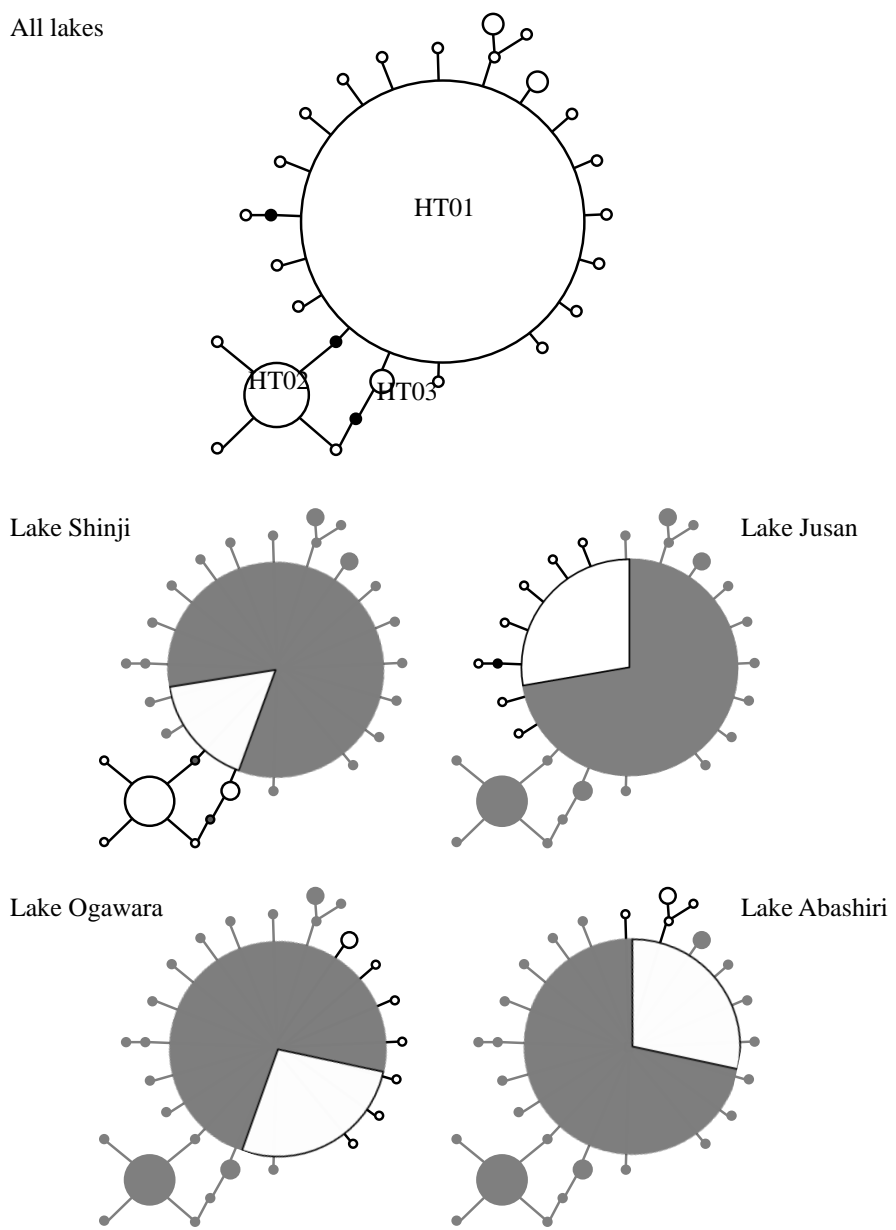

Figure 3. Minimum spanning haplotype network of Corbicula japonica collected in Lakes Shinji, Jusan, Ogawara and Abashiri. White and gray areas indicate haplotype found in individual lake and other 3 lakes, respectively. Solid line and black dot represent single base pair difference among haplotypes and putative mutational step between haplotypes, respectively. Size of circle is proportional to the number of individuals per haplotype.

$$
\begin{aligned}
& F_{\mathrm{ST}} \bigsqcup_{\text {Obashiri }}^{\text {Jusan }} \\
& \text { Ogawara Shinji } \\
& \longmapsto 0.02 \\
& \Phi_{\mathrm{ST}} \quad-\underbrace{\text { Jusan }}_{\text {Ogawara }} \\
& \text { Shinji } \\
& \stackrel{\longmapsto}{\longrightarrow 02}
\end{aligned}
$$

Figure 4. Neighbor-joining trees for Corbicula japonica collected in Lakes Shinji, Jusan, Ogawara and Abashiri based on pairwise $F_{\text {ST }}$ values and $\Phi_{\text {ST }}$ values. 
Table 2. Nucleotide variations among 25 haplotypes of Corbicula japonica collected in Lakes Shinji, Jusan, Ogawara and Abashiri.

\begin{tabular}{|c|c|c|c|c|c|c|c|c|c|c|c|c|c|c|c|c|c|c|c|c|c|c|c|c|c|c|}
\hline & \multicolumn{21}{|c|}{ Site } & \multicolumn{5}{|c|}{ Lake } \\
\hline & 159 & 61 & & 106 & 145 & 148 & 167 & 183 & 209 & 271 & 283 & 289 & 348 & 355 & 367 & 424 & 466 & 509 & 523 & 526 & 544 & Shinji & Jusan & Ogawara & Abashiri & Total \\
\hline HT01 & $\mathrm{T} \mathrm{C}$ & A & C & $\mathrm{T}$ & $\mathrm{G}$ & $\mathrm{C}$ & G & G & $\mathrm{C}$ & $\mathrm{T}$ & A & G & $\mathrm{T}$ & G & $\mathrm{T}$ & G & A & A & A & A & G & 25 & 41 & 40 & 42 & 148 \\
\hline НT02 & C. & . & . & . & . & . & . & . & . & . & . & A & . & . & . & . & . & . & . & . & . & 14 & & & & 14 \\
\hline НT03 & . & . & . & . & . & . & . & A & . & . & . & . & . & . & . & . & . & . & . & . & . & 2 & & & & 2 \\
\hline НT04 & . & . & . & . & . & . & . & . & . & . & . & . & . & . & . & . & . & . & . & . & A & 1 & & & & 1 \\
\hline HT05 & C. & . & . & . & . & $\mathrm{T}$ & . & . & . & . & . & A & . & . & . & . & . & . & . & . & . & 1 & & & & 1 \\
\hline HT06 & C. & . & . & . & . & . & . & . & . & . & . & A & . & . & . & . & . & . & . & . & . & 1 & & & & 1 \\
\hline НT07 & C. & . & . & . & . & . & . & . & . & . & . & A & . & . & . & . & . & . & . & . & A & 1 & & & & 1 \\
\hline HT08 & . & . & . & . & . & . & . & . & . & . & . & . & . & . & . & . & . & G & . & . & . & & 1 & & & 1 \\
\hline НT09 & . & . & . & . & . & . & . & . & . & . & . & . & . & . & . & A & . & . & . & . & . & & 1 & & & 1 \\
\hline HT10 & . & . & . & . & . & . & . & . & $\mathrm{T}$ & . & . & . & . & . & . & . & . & . & . & . & . & & 1 & & & 1 \\
\hline HT11 & . & . & . & . & A & . & . & . & . & . & . & . & . & . & . & . & . & . & . & . & . & & 1 & & & 1 \\
\hline HT12 & . . & G & . & . & . & . & . & . & . & . & . & . & . & . & . & . & . & . & . & . & . & & 1 & & & 1 \\
\hline HT13 & . & . & . & . & . & . & . & . & . & . & . & . & . & A & . & . & . & . & . & . & . & & 1 & & & 1 \\
\hline HT14 & . . & . & . & . & . & . & . & . & . & . & . & . & . & . & . & . & . & . & . & . & . & & 1 & & & 1 \\
\hline HT15 & . & . & . & . & . & . & . & . & . & . & . & . & A & . & . & . & . & . & . & . & . & & & 2 & & 2 \\
\hline HT16 & .. & . & . & . & . & . & . & . &. & . & . & . & . & . & . & . & . & . & G & . & . & & & 1 & & 1 \\
\hline HT17 & . & . & . & . & . & . & . & . & . & $\mathrm{C}$ & G & . & . & . & . & . & . & . & . & . & . & & & 1 & & 1 \\
\hline HT18 & . & . & . & C & . & . & . & . & . & . & . & . & . & . & . & . & . & . & . & . & . & & & 1 & & 1 \\
\hline HT19 & . & . & . & . & . & . & A & . & . & . & . & . & . & . & . & . & . & . & . & . & . & & & 1 & & 1 \\
\hline HT20 & . & . & . & . & . & . & . & . & . & . & . & . & . & . & C & . & . & . & . & . & . & & & 1 & & 1 \\
\hline HT21 & . $\mathrm{T}$ & . & . & . & . & . & . & . & . & . & . & . & . & . & . & . & . & . & . & . & . & & & 1 & & 1 \\
\hline HT22 & . & . & . & . & . & . & . & . & . & . & . & . & . & . & . & . & G & . & . & G & . & & & & 2 & 2 \\
\hline HT23 & . & . & A & . & . & . & . & . & . & . & . & . & . & . & . & . & . & . & . & . & . & & & & 1 & 1 \\
\hline HT24 & . & . & . & . & . & . & . & . & . & . & . & . & . & . & . & . & . & . & . & G & . & & & & 1 & 1 \\
\hline HT25 & . & . & . & . & . & . & . & . & . & . & . & . & . & . & . & . & . & . & . & G & . & & & & 1 & 1 \\
\hline Total & & & & & & & & & & & & & & & & & & & & & & 45 & 48 & 48 & 47 & 188 \\
\hline
\end{tabular}

Dot indicates nucleotide identical to that of HT01 sequence.

Table 3. Haplotype diversity, nucleotide diversity and number of nucleotide substitution of Corbicula japonica collected in Lakes Shinji, Jusan, Ogawara and Abashiri.

\begin{tabular}{ccccc}
\hline Lake & $n$ & Haplotype diversity & Nucleotide diversity (\%) & Nucleotide substitution \\
\hline Shinji & 45 & $0.6040 \pm 0.0566$ & $0.2207 \pm 0.1586$ & 6 \\
Jusan & 48 & $0.2730 \pm 0.0850$ & $0.0601 \pm 0.0678$ & 7 \\
Ogawara & 48 & $0.3076 \pm 0.0870$ & $0.0598 \pm 0.0675$ & 4 \\
Abashiri & 47 & $0.2026 \pm 0.0778$ & $0.0591 \pm 0.0671$ & 24 \\
Total & 188 & $0.3758 \pm 0.0453$ & $0.1171 \pm 0.1009$ & 7 \\
\hline
\end{tabular}




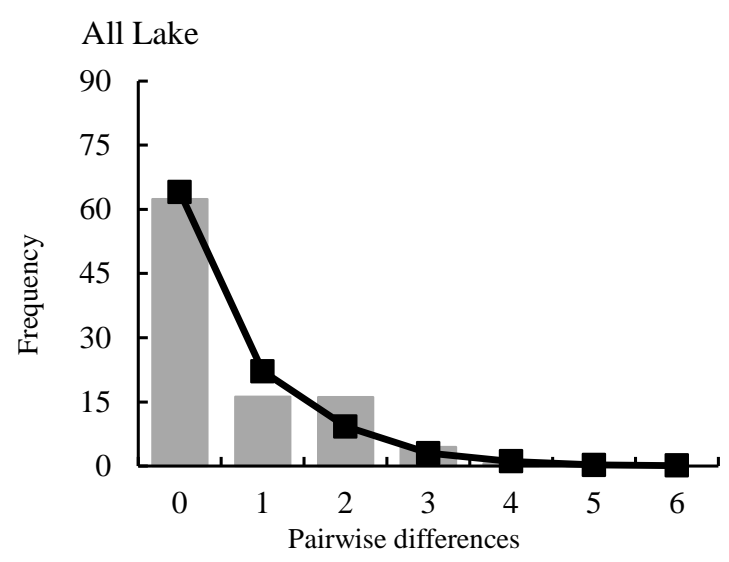

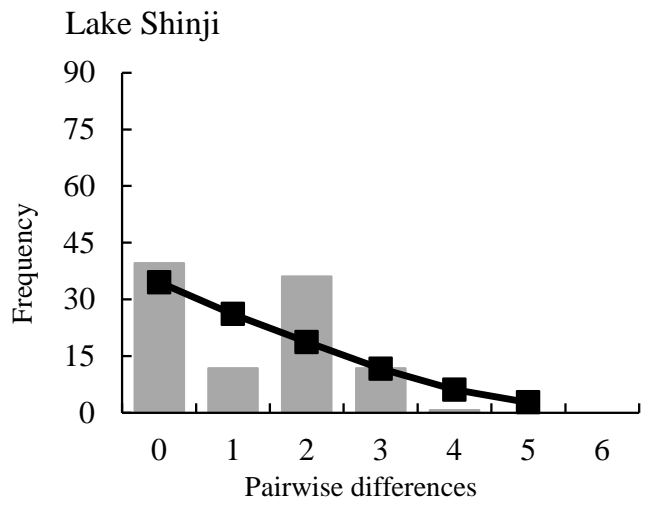

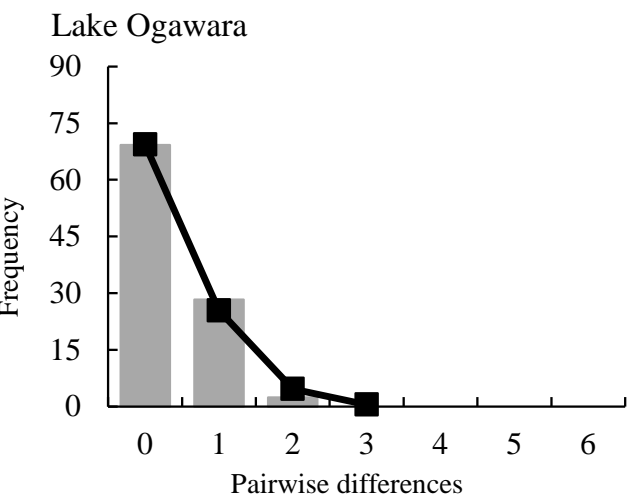

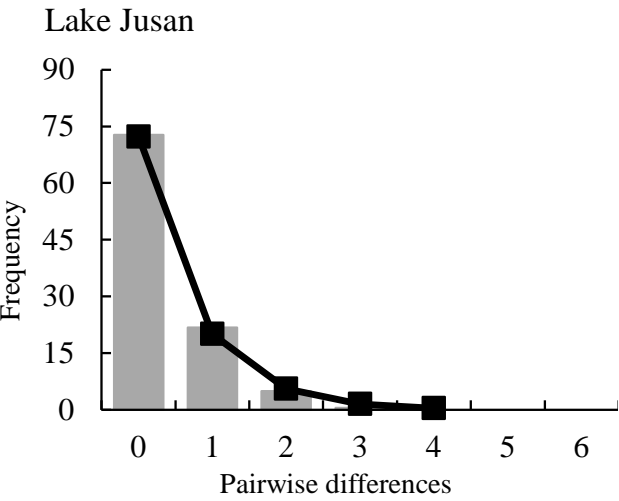

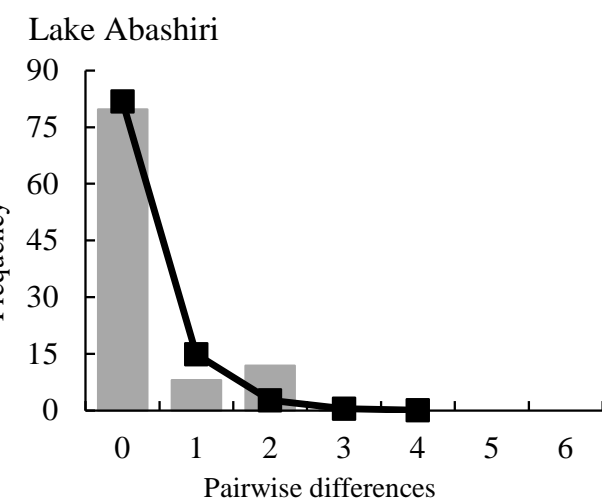

Figure 5. Mismatch distribution of Corbicula japonica collected in Lakes Shinji, Jusan, Ogawara and Abashiri. Vertical bar and solid line represent observed distribution of mismatches and expected distribution of mismatches under the spatial expansion model, respectively.

Table 4. Pairwise $F_{\mathrm{ST}}$ values (above the diagonal) and $\Phi_{\mathrm{ST}}$ values (below the diagonal) of Corbicula japonica collected in Lakes Shinji, Jusan, Ogawara and Abashiri.

\begin{tabular}{cccc}
\hline Lake & Shinji & Jusan & Ogawara \\
Shinji & & ${ }^{* *} 0.1675$ & ${ }^{* *} 0.1529$ \\
Jusan & ${ }^{* *} 0.2677$ & & -0.0074 \\
Ogawara & ${ }^{* *} 0.2682$ & 0.0027 & 0.0048 \\
Abashiri & ${ }^{* *} 0.2715$ & ${ }^{*} 0.0194$ & 0.0220
\end{tabular}

${ }^{*} p<0.05,{ }^{* *} p<0.01$ following Bonferroni correction $(\mathrm{k}=6)$. 
sum of square deviations (SSD) ranged from 0.0005 in Lake Jusan to 0.0563 in Lake Shinji with no statistical significance $(p>0.05)$, and the Harpending's raggedness index (Hri) ranged from 0.2071 in Lake Shinji to 0.5291 in Lake Abashiri with no statistical significance $(p>0.05)$ (Table 5). The Tajima's $D$ and Fu's $F_{\mathrm{S}}$ values for all lakes were estimated to be negative, and both values for Lake Shinji were not significant excepting the other lakes (Table 5). These results indicate that $C$. japonica occurred a recent expansion and formed the current geographical distribution in Japan.

\section{Discussions}

C. japonica is an endemic species of East Asia, but little is known about its biological and ecological properties in the native range, because it had been one of the most common species with abundant resources in various parts of Japan. However, its stock level declined over 40 years since 1970s, as its habitat lost due to water pollution and estuary modification [12]. To solve resources reduced, C. japonica individuals had been frequently transplanted mainly from Lake Shinji to every fishing area in Japan. These situations strengthened concerns over the genetic loss in C. japonica populations. In this study, we selected 4 major fishing brackish lakes with no introduction record to determine the genetic diversity of $C$. japonica in its native range (Figure 1).

Recent developments of genetic identification keys have helped to resolve questions surrounding bivalve genetic studies, and mtDNA markers such as 16S ribosomal RNA (rRNA) gene and COI gene were specifically developed for Corbicula species. Komaru et al. [30] reported genetic discrimination of recognized Corbicula species based on the 16S rRNA gene, which was verified as a sensitive molecular marker for species identification of marine bivalves [31] [32]. Suzuki et al. [33] reported population genetic structure of $C$. japonica in Japan based on the COI gene, which was also verified as a sensitive molecular marker for population differentiation of marine bivalves [16] [34].

In this study, the mtDNA COI gene was adopted to evaluate the genetic diversity and reproduction structure of C. japonica populations in major fishing brackish lakes (Table 2). The genetic diversity in Lake Shinji was higher than that in the other lakes (Table 3), and it therefore provided evidence of highly significant genetic differentiation between Lake Shinji and the other lakes (Figure 4, Table 4). This genetic differentiation was caused by unique population genetic structures on haplotype networks, which were radiated from the haplotypes H01 and H02 in Lake Shinji and from the haplotypes H01 alone in the other lakes (Figure 3). Otherwise, the mismatch distribution analysis indicated unimodal profile for Lakes Jusan and Ogawara and bimodal profile for Lakes Shinji and Abashiri, and the respective profiles show recent histories of population growth and continuous reproduction (Figure 5). These reproduction structures could depend on different seedling systems that were artificial mass seedling production in Lakes Jusan and Ogawara and natural seedling production in Lakes Shinji and Abashiri. All results obtained in this study allowed us to characterize the genetic diversity and reproduction structure in 4 brackish lakes as follows; continuous reproduction with a high diversity in Lake Shinji, rapidly grown reproduction with a low diversity in Lakes Jusan and Ogawara, continuous reproduction but irregular expansion with a low diversity in Lake Abashiri.

Passive dispersal of planktonic larvae may be strongly mediated by water movements, and the effect of water movements on the genetic diversity was commonly suggested in aquatic invertebrates [35] [36]. From spawning to Juveniles stage of $C$. japonica lasted approximately 12 days followed by planktonic stage to larval settlement for 54 hours to 6 days [37] [38]. Larvae reached the size of $4-5 \mathrm{~mm}$ shell length in1 year and $14-15 \mathrm{~mm}$ in 3

Table 5. Mismatch distribution of Corbicula japonica collected in Lakes Shinji, Jusan, Ogawara and Abashiri.

\begin{tabular}{cccccccc}
\hline \multirow{2}{*}{ Lake } & \multicolumn{2}{c}{ Neutral test } & \multicolumn{3}{c}{ Mismatch distribution } & \multicolumn{2}{c}{ Goodness of fit test } \\
\hline & Tajima's $D$ & Fu's $F_{\mathrm{S}}$ & $\tau$ & $\theta_{0}$ & $\theta_{1}$ & SSD & Hri \\
\hline Shinji & -0.2843 & -1.4353 & 2.4473 & 0.0000 & 2.1085 & 0.0563 & 0.2071 \\
Jusan & $-2.2416^{* *}$ & $-8.6093^{* *}$ & 3.0000 & 0.0000 & 0.3849 & 0.0005 & 0.2893 \\
Ogawara & $-2.1064^{* *}$ & $-8.6402^{* *}$ & 0.3672 & 0.0000 & 99999.0000 & 0.0014 & 0.2351 \\
Abashiri & $-1.4684^{*}$ & $-3.2927^{* *}$ & 3.0000 & 0.0000 & 0.2230 & 0.0136 & 0.5291 \\
\hline
\end{tabular}

Parameters of the spatial expansion model and goodness of fit test to the model are shown with the respective significance for each clade. SSD, sum of squared deviations; Hri, Harpending's raggedness index. ${ }^{*} p<0.05,{ }^{* * *} p<0.01$. 
years, and those with $>15 \mathrm{~mm}$ matured in Lakes Shinji [39], Ogawara [40] and Abashiri [41]. The spawning season of $C$. japonica in Lake Jusan was reported to be mid-July to late September [39], and that in Lake Ogawara was to be late July to early September [42]. It is noteworthy that C. japonica in Lake Abashiri failed to spawn from year to year due to low temperature and salinity [43]. The spawning season in Lake Shinji was, however, to be late March to early November and remarkably longer than that in the other lakes [42]. Iidzuka et al. [15] reported that the long spawning season might produce the complicated population genetic structure in Lake Shinji. It is therefore inferred that the difference of spawning in the season and length reflects in not only the genetic diversity but also the reproduction structure of $C$. japonica population in individual lake.

\section{Conclusion}

This study thoroughly compared population genetic structure of $C$. japonica among 4 major fishing brackish lakes in Japan by means of nucleotide sequence analysis of a 556 bp portion of the mtDNA COI gene. Although C. japonica is supposed to occur a recent expansion and form the current geographical distribution in Japan, its genetic diversity and reproduction structure has been developed specifically to the lakes examined in this study. In order not only to conserve $C$. japonica populations as a genetic resource but also to manage them as a fisheries stock, haphazard transplantation and import of seedlings and/or adults of $C$. japonica and its related species should be absolutely avoided.

\section{Acknowledgements}

This work was supported in part by the Budget for Strategic Operation from Shimane University.

\section{References}

[1] Counts, C.L.I. (1989) The Zoogeography and History of the Invasion of the United States by Corbicula fluminea (Bivalvia: Corbiculidae). American Malacological Bulletin. Special Edition, 2, 7-39.

[2] Renard, E., Bachmann, V., Cariou, M.L. and Moreteau, J.C. (2000) Morphological and Molecular Differentiation of Invasive Freshwater Species of the Genus Corbicula (Bivalvia, Corbiculidae) Suggest the Presence of Three Taxa in French Rivers. Molecular Ecology, 9, 2009-2016. http://dx.doi.org/10.1046/j.1365-294X.2000.01104.X

[3] Lee, T., Siripattrawan, S., Ituarte, C.F. and O’Foighil, D. (2005) Invasion of the Clonal Clams: Corbicula Lineages in the New World. American Malacological Bulletin, 20, 113-122.

[4] Okamoto, A. and Arimoto, B. (1986) Chromosomes of Corbicula japonica, C. sandai and C. lenea (Bivalvia: Corbiculidae). Venus, 45, 194-202.

[5] Sakai, H., Kamiyama, J., Jeon, S.R. and Amio, M. (1994) Genetic Relationships among Three Species of Freshwater Bivalves Genus Corbicula (Corbiculidae) in Japan. Nippon Suisan Gakkaishi, 60, 605-610. http://dx.doi.org/10.2331/suisan.60.605

[6] Harada, E. and Nishino, M. (1995) Differences in Inhalant Siphonal Papillae among the Japanese Species of Corbicula (Mollusca: Bivalvia). Publications of the Seto Marine Biological Laboratory, 36, 389-408.

[7] Komaru, A., Konishi, K., Nakayama, I., Sakai, H. and Kawamura, K. (1997) Hermaphroditic Freshwater Clams in the Genus Corbicula Produce Non-Reductional Spermatozoa with Somatic DNA Content. The Biological Bulletin, 193, 320-323. http://dx.doi.org/10.2307/1542934

[8] Nanbu, R., Mizuno, T. and Sekiguchi, H. (2008) Post-Settlement Growth and Mortality of Brackish Water Clam Corbicula japonica in the Kiso Estuaries, Central Japan. Fisheries Science, 74, 1254-1268. http://dx.doi.org/10.1111/j.1444-2906.2008.01650.x

[9] Oshima, K., Suzuki, N., Nakamura, M. and Sakuramoto, K. (2004) Shell Growth and Age Determination of the Brackish Water Bivalve Corbicula japonica in Lake Shinji, Japan. Fisheries Science, 70, 601-610. http://dx.doi.org/10.1111/j.1444-2906.2004.00847.x

[10] Ministry of Agriculture, Forestry, and Fisheries (2012) Statistical Data Database System of Agriculture, Forestry, and Fisheries, Japan. Ministry of Agriculture, Forestry, and Fisheries, Tokyo. http://www.e-stat.go.jp/SG1/estat/List.do?lid=000001116218

[11] Nakamura, M. (2011) Brackish Water Clam. Japan Fisheries Resource Conservation Association, Tokyo.

[12] Nakamura, M. (2000) Nippon No Sijimi Gyogyo. Tatara Shobo, Matsue.

[13] Avise, J.C. (2000) Phytogeography: The History and Formation of Species. Harvard University Press, Cambridge, Massachusetts. 
[14] Mito, T. and Aranishi, F. (2010) Molecular Taxonomical Analysis of Freshwater Corbicula Clam from the Takahashi River. Japanese Journal of Limnology, 71, 193-199. http://dx.doi.org/10.3739/rikusui.71.193

[15] Iidzuka, Y., Mito, T., Noda, K., Iwasaki, T., Tanaka, T., Yokoo, T. and Aranishi, F. (2010) Genetic Diversity of Yamatoshijimi Clam Corbicula japonica in Lake Shinji, Japan. Research Report of the Research and Education Center for Inlandwater Environment Shinshu University, 6,115-124.

[16] Tanaka, T. and Aranishi, F. (2014) Genetic Variability and Population Structure of Ark Shell in Japan. Open Journal of Marine Science, 4, 8-17. http://dx.doi.org/10.3739/rikusui.71.193

[17] Aranishi, F. (2006) A Novel Mitochondrial Intergenic Spacer Reflecting Population Structure of Pacific Oyster. Journal of Applied Genetics, 47, 119-123. http://dx.doi.org/10.1007/BF03194610

[18] Aranishi, F. and Okimoto, T. (2004) Genetic Relationship between Cultured Populations of Pacific Oyster Revealed by RAPD Analysis. Journal of Applied Genetics, 45, 435-443.

[19] Aranishi, F. and Okimoto, T. (2005) Sequence Polymorphism in a Novel Noncoding Region of Pacific Oyster Mitochondrial DNA. Journal of Applied Genetics, 46, 201-206.

[20] Folmer, O., Black, M., Hoeh, W., Lutz, R. and Vrijenhoek, R. (1994) DNA Primers for Amplification of Mitochondrial Cytochrome $c$ Oxidase Subunit I from Diverse Metazoan Invertebrates. Molecular Marine Biology and Biotechnology, 3, 294-299.

[21] Thompson, J.D., Higgins, D.G. and Gibson, T.J. (1994) CLUSTAL W: Improving the Sensitivity of Progressive Multiple Sequence Alignment through Sequence Weighting, Position-Specific Gap Penalties and Weight Matrix Choice. Nucleic Acids Research, 22, 4673-4680. http://dx.doi.org/10.1093/nar/22.22.4673

[22] Tamura, K., Peterson, D., Peterson, N., Stecher, G., Nei, M. and Kumar, S. (2011) MEGA5: Molecular Evolutionary Genetics Analysis Using Maximum Likelihood, Evolutionary Distance, and Maximum Parsimony Methods. Molecular Biology and Evolution, 28, 2731-2739. http://dx.doi.org/10.1093/molbev/msr121

[23] Clement, M., Posada, D. and Crandall, K. (2000) TCS: A Computer Program to Estimate Gene Genealogies. Molecular Ecology, 9, 1657-1660. http://dx.doi.org/10.1046/j.1365-294x.2000.01020.x

[24] Excoffier, L. and Lischer, H.E.L. (2010) Arlequin suite ver 3.5: A New Series of Programs to Perform Population Genetics Analyses under Linux and Windows. Molecular Ecology Resources, 10, 564-567. http://dx.doi.org/10.1111/j.1755-0998.2010.02847.x

[25] Rice, W.R. (1989) Analyzing Tables of Statistical Tests. Evolution, 43, 223-225. http://dx.doi.org/10.2307/2409177

[26] Kimura, M. (1980) A Simple Method for Estimating Evolutionary Rates of Base Substitutions through Comparative Studies of Nucleotide Sequences. Journal of Molecular Evolution, 16, 111-120. http://dx.doi.org/10.1007/BF01731581

[27] Felsenstein, J. (2005) PHYLIP (Phylogeny Inference Package) Version 3.6. Department of Genome Sciences, University of Washington, Seattle.

[28] Tajima, F. (1989) Statistical Method for Testing the Neutral Mutation Hypothesis by DNA Polymorphism. Genetics, 123, 585-595.

[29] Fu, Y.X. (1997) Statistical Tests of Neutrality against Population Growth, Hitchhiking and Background Selection. Genetics, 147, 915-925.

[30] Komaru, A., Hori, H., Yanase, Y., Onouchi, K., Kato, T., Ishibashi, R., Kawamura, K., Kobayashi, M. and Nishida, M. (2010) Mitochondrial 16S rDNA Analysis Used to Distinguish Corbicula japonica from Japan and Imported Species from Korea and China. Nippon Suisan Gakkaishi, 76, 621-629. http://dx.doi.org/10.2331/suisan.76.621

[31] Aranishi, F. and Iidzuka, Y. (2007) Multiplex PCR Diagnosis for Crassostrea Oyster Discrimination of C. sikamea and C. gigas. Journal of Fisheries and Aquatic Science, 2, 173-177. http://dx.doi.org/10.3923/jfas.2007.173.177

[32] Iidzuka, Y. and Aranishi, F. (2008) DNA Fingerprinting for Ostreidae Oysters in Kyushu. Laguna, 15, 69-76.

[33] Suzuki, M., Kanno, M. and Kijima, A. (2009) Geographic Distribution and Genetic Population Structure of Corbicula japonica around East Asia Estimated by mtDNA COI Sequence Analysis. Proceedings of World Fisheries Congress 2008, 455.

[34] Tanaka, T. and Aranishi, F. (2013) Mitochondrial DNA Markers for PCR-Based Phylogenetic Analysis of Ark Shells. Open Journal of Marine Science, 3, 182-189. http://dx.doi.org/10.4236/ojms.2013.34021

[35] Lessios, H.A., Kessing, B.D., and Pearse, J.S. (2001) Population Structure and Speciation in Tropical Seas: Global Phylogeography of the Sea Urchin Diadema. Evolution, 55, 955-975. http://dx.doi.org/10.1111/j.0014-3820.2001.tb00613.x

[36] Waters, J.M. and Roy, M.S. (2004) Phylogeography of High-Dispersal New Zealand Sea-Star: Does Upwelling Block Gene-Flow? Molecular Ecology, 13, 2797-2806. http://dx.doi.org/10.1111/j.1365-294X.2004.02282.x

[37] Tanaka, Y. (1984) Salinity Tolerance of the Brackish-Water Clam, Corbicula japonica Prime. Bulletin of National Research Institute of Aquaculture, 6, 29-32. 
[38] Kimura, T., Soutome, Y. and Sekiguchi, H. (2004) Larval Development of the Brackish Water Clam Corbicula japonica (Bivalvia: Corbiculidae), with Special Reference to Morphological Comparison with Concurrent Tidal Flat Bivalves. Venus, 63, 33-48.

[39] Moriwaki, S., Wakabayashi, H., Miura, T. and Yamane, T. (2009) Fisheries Biology of Corbicula japonica in Lake Shinji, Japan-Its Present Condition and Effects on Resources Management. Report of Shimane Prefectural Fisheries Technology Center, 2, 31-38.

[40] Fuji, A. (1997) Ecology and Stock of the Brackish Water Bivalve Corbicula japonica in Lake Ogawara. Comprehensive Report. In: Report of Research on Fisheries in Lake Ogawara. Final Comprehensive Study, Construction Office for the Comprehensive Development of the Takase River of Tohoku Regional Construction Bureau, Aomori, 33-73.

[41] Maru, K. (1981) Reproductive Cycle of the Brackish-Water Bivalve, Corbicula japonica, in Lake Abashiri. Scientific Reports of Hokkaido Fisheries Experimental Station, 23, 83-95.

[42] Baba, K., Tada, M., Kawajiri T. and Kuwahara, Y. (1999) Effects of Temperature and Salinity on Spawning of the Brackish Water Bivalve Corbicula japonica in Lake Abashiri, Hokkaido, Japan. Marine Ecology Progress Series, 180, 213-221. http://dx.doi.org/10.3354/meps180213

[43] Narita, T., Hosoi, T., Nagasaki, M. and Komaru, A. (2006) Spawning Possibility of Corbicula japonica under Low Sanlinity Condition in Lake Ogawara, Aomori, Japan. Suisanzoshoku, 54, 201-208. 
Scientific Research Publishing (SCIRP) is one of the largest Open Access journal publishers. It is currently publishing more than 200 open access, online, peer-reviewed journals covering a wide range of academic disciplines. SCIRP serves the worldwide academic communities and contributes to the progress and application of science with its publication.

Other selected journals from SCIRP are listed as below. Submit your manuscript to us via either submit@scirp.org or Online Submission Portal.
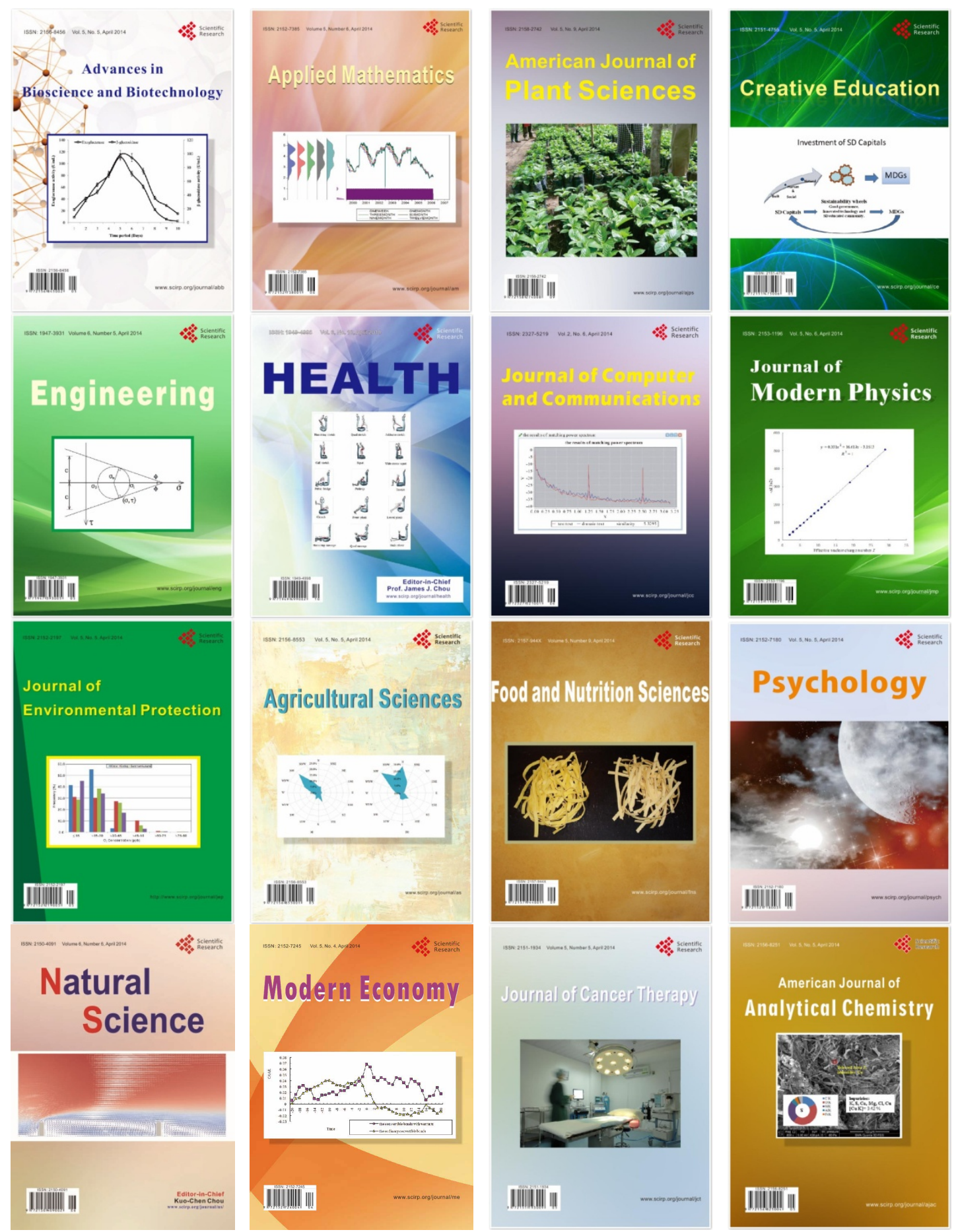